\title{
An Asset for an International Investor: The Colombian MFIs
}

\author{
Carmelo Intrisano $^{1} \&$ Anna Paola Micheli ${ }^{2}$ \\ ${ }^{1}$ Professor of Corporate Finance, Department of Economy and Law, University of Cassino, Italy \\ ${ }^{2}$ Phd and Research Fellow in Corporate Finance, University of Cassino and Southern Lazio, Cassino, Italy \\ Correspondence: Carmelo Intrisano, Professor of Corporate Finance, Department of Economy and Law, \\ University of Cassino, Sant' Angelo Road, Cassino, Italy. E-mail: c.intrisano@unicas.it
}

Received: July 1, 2015

Accepted: July 21, 2015

Online Published: July 25, 2015

doi:10.5539/ibr.v8n8p191

URL: http://dx.doi.org/10.5539/ibr.v8n8p191

\begin{abstract}
The present paper aims to contribute to the framework of knowledge on Colombian system of microcredit, taking as perspective an investor who collects on international market through the issue of bonds in order to finance microfinance institutions in Colombia. In this way we want to show how microcredit can be fed by international markets who see this form of investment as an opportunity to raise yields. To realize this there is a financial system with high specialization on microcredit institution and the need for funding by the institutions themselves. The paper analyzes the system of microcredit as a whole and then moves onto the observation and consequent determination of economic and financial variables of Microfinance Institutions (MFIs).
\end{abstract}

Keywords: microfinance institution, carry trade, microcredit system, international investor

\section{Introduction}

Among the Latin American countries, Colombia has a micro-financial system very consolidated, in fact, a large number of NGOs offer microcredit, but there are also banks and regulated institutions. The study shows that the rates charged on microcredit are higher than interest rates on other financial products: the main explanations are due to the high risk implicit in the activity of micro-credit, high cost of finance and the high operating costs associated with the microcredit and the need to overcome the lack of funding sources which are low-cost deposits. With regard to Colombia, microcredit is not particularly risky, and the level of bad loans is not significantly higher than that of other financial products. To demonstrate this, after a survey of literature review, we estimated the potential investment that it represents for an international investor. In particular, methodologically, we have carry out an analysis of the financial structure for each Microcredit Institutions, reconstructing the values of loans, deposits and equity capital and calculating the following indicators:

* Net requirement of the loans portfolio= Credits - Deposits - Equity

* Net requirement ratio $=($ Loans - Deposits - Equity $) /$ Loans

These indicators allow to identify those potential companies where international investor could direct its activity.

\section{Literature Review}

The microfinance market in the countries of Latin America is one of the oldest and most developed (Miller, 2003), covering a very important role within the financial sector. Although it is characterized by a myriad of institutions different in size and performance, it still has common features. The MFIs may be defined as a group of organizations that have found innovative and new methodologies to overcome a number of problems related to loan (Vanroose, 2008), financial development, in fact, in developing countries, has been pursued, also through an intense process of liberalization and globalization of commercial banking services (Hanson, 2003; Cull \& Martinez Peria, 2010). Increasingly, microcredit has been regarded as an extremely useful tool to provide access to credit to every section of the population traditionally discriminated by ordinary banks. Economists have theoretically justified the granting of the loan by microcredit institutions in relation also to the high rates charged (Besley \& Coate, 1995; Stiglitz, 1990; Varian, 1990). Part of the literature argues that Latin American MFIs are more trade-oriented than their colleagues in Africa and Asia (Lapenu \& Zeller, 2001; Ramirez, 2004; Vanroose \& Armendáriz, 2009). It is also interesting the point of view of Bateman (2013) who believes that microfinance is contributing in some way to the de-industrialization of the country in South America. Janda et al. (2014) instead lead an analysis designed to determine an approach to the setting of interest rates by the institutions of micro 
finance. Essentially they attempt to tie the rate with different macroeconomic variables. The microcredit also plays a major role in Colombia, a country in which micro, small and medium enterprises have great impact on the employment situation (Chamorro-Narvaez, 2012). Considering the growing development, a new field of investigation can be found, a field that is aimed at mutual funds and their strategies. Given the high rates charged by microfinance institutions, an investment in such companies by specialized funds could be attractive for two mainly reasons: low correlation of micro finance institutions with the trend in global capital markets, and therefore good diversification opportunities (Krausset et al., 2009); carry trade practice is treated also by Nucera et al. (2013). They highlight the use of this technique by hedge funds in order to generate extra return. In this paper we will focus on this issue, analyzing the Colombian situation. The carry trade is a very topical theme in the scientific literature, Galati et al. (2012) argue that in an economic environment, in which interest rate differentials have been a driving force of the movement in exchange rates during recent years, the possible settlement of open positions could adversely affect financial stability. Plantinet et al. (2011) support a similar argument, which defines carry trade as an important element in the financial stability.

\section{The Analysis of Microcredit System}

The Colombian financial system is represented by two main banking institutions that have public nature:

- BANCOLDEX (C RADE Bank of Foreign of Colombia), that is the development bank in the system. It guides the productivity of the entrepreneurship toward the innovation, modernization and internationalization.

- Banco de la Rep ù Republic (Banc in the Republic of Colombia), which is the Central Bank of Colombia, with powers of supervision over the country's financial system.

The private sector of lending to businesses and to households consists mainly of commercial banks and microfinance and leasing institutions, with asset portfolios that are distributed, as we can see in the following table, according to the total of enterprises that belong to the private sector of lending.

Table 1. Distribution of ordinary activities of credit and microcredit

\begin{tabular}{cccccc}
\hline \multirow{2}{*}{ Private lending sector } & \multicolumn{2}{c}{ June-2013 } & \multicolumn{2}{c}{ June-2014 } & Annual real growth rate \\
\cline { 2 - 5 } & Billions of pesos & $\%$ & Billions of pesos & $\%$ & 8,74 \\
\hline Portfolio & 140,32 & $89,42 \%$ & 152,58 & $97,23 \%$ & 8,62 \\
Commercial & 132,4 & $84,37 \%$ & 143,82 & $91,65 \%$ & 10,73 \\
Microcredit & 7,91 & $5,04 \%$ & 8,76 & $5,58 \%$ & 3,55 \\
Financial Leasing & 15,91 & $10,14 \%$ & 16,48 & $10,50 \%$ & 3,57 \\
Commercial & 15,91 & $10,14 \%$ & 16,47 & $10,50 \%$ & $-38,47$ \\
Mecurities & 0,01 & $0,01 \%$ & 0 & $0,00 \%$ & 16,19 \\
\hline Total & 0,69 & $0,44 \%$ & 0,8 & $0,51 \%$ & 8,25 \\
\hline
\end{tabular}

Source: Ourelaboration on Banco de la Repùblica data.

About the ownership of financial products by customers, in the third quarter of 2014 there are 23,239,287 customers that have one financial product at least, an increase compared to the same period last year, in which the holders of financial products amounted to $21,791,836$. Compared to the total population, therefore, the index of "banked" estimated for the third quarter of 2014 amounted to $72.6 \%$, against $69.3 \%$ a year earlier. In particular, the number of people who have at least a financial product is shown below, also according to the type of product that they possess. It is also represented the growth in the years for each type of product. 
Table 2. Number of people with at least a financial product and growth in September 2013-2014 and June 2014-September 2014

\begin{tabular}{crrrrrr}
\hline & \multicolumn{4}{c}{ Number of people with financial products } & \multicolumn{2}{c}{ Growth } \\
\cline { 2 - 7 } & \multicolumn{1}{c}{$\mathbf{2 0 1 1}$} & \multicolumn{1}{c}{$\mathbf{2 0 1 2}$} & $\mathbf{2 0 1 3}$ & $\mathbf{2 0 1 4}$ & sept 13-sept 14 & June 14-sept 14 \\
\hline Saving account & $18,022,079$ & $19,299,813$ & $20,096,322$ & $21,622,624$ & $7.6 \%$ & $2.8 \%$ \\
Bank account & $1,438,659$ & $1,498,835$ & $1,528,229$ & $1,540,834$ & $0.8 \%$ & $0.8 \%$ \\
Consumption & $4,243,059$ & $4,851,998$ & $4,997,868$ & $5,471,422$ & $9.5 \%$ & $2.4 \%$ \\
Loan & 716,739 & 761,130 & 820,592 & 873,878 & $6.5 \%$ & $1.4 \%$ \\
Microcredit & $1,484,261$ & $1,677,273$ & $1,762,437$ & $1,834,924$ & $4.1 \%$ & $4.8 \%$ \\
Credit card & $5,499,377$ & $5,908,598$ & $6,494,279$ & $7,006,889$ & $7.9 \%$ & $2.3 \%$ \\
Electronic filing & & 455,145 & $1,763,118$ & $2,089,875$ & $18.5 \%$ & $2.7 \%$ \\
\hline
\end{tabular}

Source: Our elaborate onAsobancaria-CIFIN data.

The same situation is also reported for the companies that own at least one banking product. It is also showed the growth of companies that own each type of product in the periods September 2013-September 2014 and June 2014-September 2014.

Table 3. Number of firms with at least one financial product and growth in September 201-2014 and June 2014-September 2014

\begin{tabular}{ccccccc}
\hline & \multicolumn{2}{c}{ Number of enterprises with financial products } & \multicolumn{2}{c}{ Growth } \\
\cline { 2 - 7 } & $\mathbf{2 0 1 1}$ & $\mathbf{2 0 1 2}$ & $\mathbf{2 0 1 3}$ & $\mathbf{2 0 1 4}$ & sept 13-sept 14 & June 14-sept 14 \\
\hline Saving account & 311,382 & 317,559 & 383,396 & 415,661 & $8.4 \%$ & $0.7 \%$ \\
Bank account & 310,828 & 307,517 & 307,517 & 366,666 & $19.2 \%$ & $0.7 \%$ \\
Commercial & 148,102 & 163,644 & 180,765 & 186,070 & $2.9 \%$ & $2.0 \%$ \\
Consumption & 65,042 & 66,332 & 72,577 & 73,968 & $1.9 \%$ & $-0.7 \%$ \\
Microcredit & 8,323 & 8,863 & 6,496 & 7,866 & $21.1 \%$ & $5.2 \%$ \\
Credit card & 68,583 & 69,522 & 77,049 & 83,238 & $8.0 \%$ & $1.1 \%$ \\
\hline
\end{tabular}

Source: Our elaboration on Asobancaria-CIFIN data.

Regarding micro-enterprises, $51.7 \%$ asked mainly microcredit loans, $24.8 \%$ called for trade receivables, $15.3 \%$ asked for consumer credit and $8.2 \%$ asked for other types of loans (8.2\%), including credits for the purchase of a vehicle or loans for house purchase. In addition, the percentages for the different types of amounts required by microenterprises are distributed as follows for economic sectors:

Table 4. Structure of the type of credit required by the micro-economic sectors of commerce, industry and services (2014)

\begin{tabular}{cccccc}
\hline \multirow{2}{*}{ Sector } & \multicolumn{5}{c}{ Type of Credit (\%) } \\
\cline { 2 - 6 } & Microcredit & Consumer Credit & Commercial credit & Other & Total \\
\hline Business & 50.8 & 14.6 & 27.9 & 6.7 & $100 \%$ \\
Services & 55.4 & 16.8 & 19.9 & 7.9 & $100 \%$ \\
Industry & 51.6 & 18.9 & 23.6 & 5.9 & $100 \%$ \\
\hline
\end{tabular}

Source: Our elaboration on DANE data.

The companies that operate in the market of credit belong to four different categories: banks, cooperative banks, 
non-governmental organizations (NGOs) and non-banking financial institutions matrix (NBFI). The categories in which are divided the Colombian credit institutions (banks, cooperative banks, finance companies, NGOs) are each regulated by different rules. Banks are subject to the supervision of the Superintendencia Financiera Colombiana (SFC). In particular, this institution oversees both on the banks and on some co-operative institutions, in order to protect the savings of the undifferentiated public, to preserve the integrity of the financial system and the interests of individuals and institutions. In addition to the ordinary laws that govern other cooperatives, for the cooperatives of savings and credit (Cooperatives de ahorro y crédito-CAC) there are special laws and decrees. From an organizational standpoint, the CAC in Colombia are independent institutions, as in most Latin American countries, while in some of them (for example, Bolivia, Chile and Panama) cooperative institutions are integrated into a Ministry as Districts. In other countries (Brazil, Mexico and Peru) CAC do not exist. In Colombia there is an institute dedicated to security of the cooperatives. It does not matter what activity the cooperatives perform. This institute performs the same functions of the Superintendencia Financiera on banks and it is represented by Supersolidaria (SES), which monitors on cooperatives that are not covered by the supervision of the Superintendencia Financiera.

The NGOs are now unregulated corporation and therefore they are not supervised by Superintentencia Financiera and they are included within the so-called "third sector", that is complementary to the first two traditional sectors, that are private sector with profit goals and public sector. NGOs are in the form of foundations, cooperatives, associations and non-profit corporations, whose social objective is to foster the development of the whole community. These institutions, more and .more numerous in Colombia and in general in Latin America, play a very important role: in fact, they offer micro-loans to the most disadvantaged part of the population that cannot call on banks (unbanked population), The unbanked population is mostly represented by rural population that works in agriculture. So the interest rates charged by these companies are often very high, even higher than bank rates. This is due to two main reasons: the first is that clients of microcredit NGOs offer no guarantees, but the loans are assigned evaluating the temper of the person, the second is that the banks have special tax breaks that are not designed for this type of institutions (the application of 19\% VAT on interest rate).

Although NGOs are not supervised by the SFC, but some years ago a regulatory process with the aim of promoting transparency of the same NGOs started. For this purpose it has been established many associative networks in which NGOs can converge, which include, for example, the Red de ONG por la Transparencia, the Federación de Antioqueña NGOs and the Confederación Colombiana de NGOs, which are intended to promote the development of the most disadvantaged areas of the country and decrease of the poverty rate. The various institutions are present in the country, through subsidiaries and branches, according to the distribution shown in the table below, in which institutions are divided by their position. Institutions may be present in city or rural areas.

Table 5. Distribution of various types of credit institutions in rural and urban areas (2013)

\begin{tabular}{|c|c|c|c|c|c|c|c|c|c|c|}
\hline & \multicolumn{10}{|c|}{ Physical coverage by type of institution } \\
\hline & \multicolumn{2}{|c|}{ Banks } & \multicolumn{2}{|c|}{ Financing companies } & \multicolumn{2}{|c|}{ Cooperative } & \multicolumn{2}{|c|}{ NGOs } & \multicolumn{2}{|c|}{ Total } \\
\hline & Branches & Agencies & Branches & Agencies & Branches & Agencies & Branches & Agencies & Branches & Agencies \\
\hline City & 7,868 & 1,328 & 732 & 29 & 34 & 377 & 1,315 & 308 & 9,949 & 2,042 \\
\hline Rural & 37,132 & 4,070 & 3,413 & 628 & 10 & 570 & 813 & 292 & 41,368 & 5,560 \\
\hline Total & 45,000 & 5,398 & 4,145 & 657 & 44 & 947 & 2,128 & 600 & 51,317 & 7,602 \\
\hline
\end{tabular}

Source: Our elaboration on DANE data.

The highest concentration is in the capital of Colombia, Bogota, where there is $37 \%$ of the total, and in a few other districts, including Antioquia with 10.4\%, Valle del Cauca, also with 10.4\%, Santander with 6\%, Cundinamarca, and Atlántico with $5.4 \%$ and $5.1 \%$.

The contact points per 10,000 inhabitants per department are located throughout the area with roughly the same distribution of the contact points just analyzed, with some differences. In particular, the department with the highest number of points of contact for 10,000 inhabitants is Bogotá with 34 contact points, followed by Santander with 21, both Casanare and Risaralda with 19, Valle del Cauca, Meta, Cundinamarca, and Atlántico with 16 and then all other with a smaller number of contact points per 10,000 inhabitants. 
According to the division of institutions that provide microcredit services, we have the distribution of the portfolio of credit to microenterprise for each category of institution. The microenterprise credit coincides with microcredit, because microfinance is considered as the total of financial services oriented to the development of small economy, especially micro-enterprises. In particular, in the following table we show the participation of entities supervised by the Superintendencia Financiera, the participation of NGOs and the participation of cooperatives supervised by the Superintendencia de la Economia Solidaria, which contribute to the portfolio of microcredit respectively $73.78 \%, 18.57 \%$ and $7.65 \%$.

Table 6. Microcredit portfolio by type of institution (December 2014)

\begin{tabular}{|c|c|c|c|}
\hline \multicolumn{3}{|c|}{ Credit Portfolio for Microenterprise (In thousands of pesos) } & Participation $(\%)$ \\
\hline \multirow{5}{*}{$\begin{array}{l}\text { Type of institution } \\
\text { supervised by } \\
\text { Superfinanciera }\end{array}$} & Agricoltural Banks & $5,183,718$ & $56.63 \%$ \\
\hline & Other banks & $3,382,630$ & $36.95 \%$ \\
\hline & Financial companies & 465,166 & $5.08 \%$ \\
\hline & Cooperative & 119,614 & $1.31 \%$ \\
\hline & Leasing of Microcredit & 3,131 & $0.03 \%$ \\
\hline \multicolumn{2}{|c|}{ Microcredit of Superfinanciera (with Cooperative Financial and Leasing) } & $9,154,259$ & $73.78 \%$ \\
\hline \multicolumn{2}{|r|}{ NGO } & $2,304,392$ & $18.57 \%$ \\
\hline \multicolumn{2}{|r|}{ Cooperative of Supersolidaria } & 949,453 & $7.65 \%$ \\
\hline \multicolumn{2}{|r|}{ Total Portfolio of Microcredit } & $12,408,103$ & $100.00 \%$ \\
\hline
\end{tabular}

Source: Our elaboration Superintendencia Financiera de Colombia, Superintendencia de la Economia Solidaria, Confecoop, ConseioSuperior de la Microempresa.

\section{Geographical Distribution of Credit Products}

We analyzed the geographical distribution of the credit for each District in the years 2012 and 2013 and the related percentage change, and also the partition of credit for products type in the same years. The values are sorted from largest to smallest considering the size of the gross portfolio of districts. It can be seen that the highest concentration of loans of each type is located in Bogota, the Capital District (45.3\% of the total gross portfolio in Colombia in 2013), followed by Valle del Cauca, Atlántico and Santander. In the charts we report only the top twenty districts, as recorded by the most significant results.

Table 7. Distribution of the Portfolio gross and credit products for the department (2012-2013) and percentage $\Delta$

\begin{tabular}{|c|c|c|c|c|c|c|c|c|c|}
\hline \multirow[t]{2}{*}{ Districts } & \multicolumn{3}{|c|}{ Gross portfolio (in millions of pesos) } & \multicolumn{3}{|c|}{$\begin{array}{l}\text { Microcredit (in millions of } \\
\text { pesos) }\end{array}$} & \multicolumn{3}{|c|}{$\begin{array}{l}\text { Ordinary credit and leasing (in } \\
\text { millions of pesos) }\end{array}$} \\
\hline & 2012 & 2013 & $\Delta \%$ & 2012 & 2013 & $\Delta \%$ & 2012 & 2013 & $\Delta \%$ \\
\hline Bogotá D.C. & $109,097,945$ & $124,400,309$ & $14.03 \%$ & 783,081 & 844,084 & $7.79 \%$ & $69,924,936$ & $78,920,234$ & $12.86 \%$ \\
\hline Valle del Cаиса & $21,516,274$ & $24,671,808$ & $14.67 \%$ & 537,173 & 573,915 & $6.84 \%$ & $13,763,391$ & $15,733,177$ & $14.31 \%$ \\
\hline Atlántico & $15,722,538$ & $15,897,409$ & $1.11 \%$ & $1,163,468$ & $1,176,408$ & $1.11 \%$ & $10,628,435$ & $10,746,648$ & $1.11 \%$ \\
\hline Santander & $9,812,288$ & $11,510,776$ & $17.31 \%$ & 432,706 & 532,338 & $23.03 \%$ & $5,589,176$ & $6,600,828$ & $18.10 \%$ \\
\hline Bolivar & $4,881,122$ & $5,581,612$ & $14.35 \%$ & 134,185 & 171,358 & $27.70 \%$ & $2,852,130$ & $3,193,363$ & $11.96 \%$ \\
\hline Cundinamarca & $3,885,811$ & $4,819,904$ & $24.04 \%$ & 553,594 & 644,739 & $16.46 \%$ & $1,142,619$ & $1,390,774$ & $21.72 \%$ \\
\hline Tolima & $3,688,975$ & $4,237,916$ & $14.88 \%$ & 333,027 & 382,839 & $14.96 \%$ & $1,592,596$ & $1,841,823$ & $15.65 \%$ \\
\hline Risaralda & $3,422,760$ & $4,019,430$ & $17.43 \%$ & 108,801 & 119,215 & $9.57 \%$ & $1,680,185$ & $2,032,356$ & $20.96 \%$ \\
\hline Huila & $2,883,421$ & $3,268,786$ & $13.36 \%$ & 456,396 & 528,975 & $15.90 \%$ & $1,094,492$ & $1,222,140$ & $11.66 \%$ \\
\hline Meta & $2,882,416$ & $3,315,360$ & $15.02 \%$ & 189,113 & 237,133 & $25.39 \%$ & $1,297,306$ & $1,484,933$ & $14.46 \%$ \\
\hline Caldas & $2,822,138$ & $3,225,954$ & $14.31 \%$ & 170,437 & 195,486 & $14.70 \%$ & $1,320,910$ & $1,597,780$ & $20.96 \%$ \\
\hline
\end{tabular}




\begin{tabular}{|c|c|c|c|c|c|c|c|c|c|}
\hline Norte de Santander & $2,648,650$ & $3,003,941$ & $13.41 \%$ & 228,298 & 261,728 & $14.64 \%$ & 945,646 & $1,054,816$ & $11.54 \%$ \\
\hline Córdoba & $2,189,168$ & $2,577,495$ & $17.74 \%$ & 189,584 & 240,091 & $26.64 \%$ & $1,013,190$ & $1,112,444$ & $9.80 \%$ \\
\hline Boyacá & $2,164,630$ & $2,551,215$ & $17.86 \%$ & 0 & 0 & $0.00 \%$ & 839,241 & 993,630 & $18.40 \%$ \\
\hline Nariño & $2,016,506$ & $2,344,282$ & $16.25 \%$ & 468,422 & 551,587 & $17.75 \%$ & 600,448 & 715,217 & $19.11 \%$ \\
\hline Magdalena & $1,798,327$ & $2,125,682$ & $18.20 \%$ & 190,623 & 225,322 & $18.20 \%$ & 708,541 & 837,519 & $18.20 \%$ \\
\hline Cesar & $1,623,531$ & $1,875,329$ & $15.51 \%$ & 154,274 & 175,441 & $13.72 \%$ & 575,046 & 642,180 & $11.67 \%$ \\
\hline Quindio & $1,283,807$ & $1,472,179$ & $14.67 \%$ & 68,386 & 74,705 & $9.24 \%$ & 464,940 & 543,477 & $16.89 \%$ \\
\hline Cauca & $1,145,962$ & $1,423,620$ & $24.23 \%$ & 186,957 & 256,571 & $37.24 \%$ & 350,446 & 423,911 & $20.96 \%$ \\
\hline Casanare & 921,905 & $1,147,067$ & $24.42 \%$ & 85,397 & 109,496 & $28.22 \%$ & 356,681 & 448,615 & $25.77 \%$ \\
\hline Sucre & 905,888 & $1,043,300$ & $15.17 \%$ & 98,141 & 120,204 & $22.48 \%$ & 340,501 & 385,408 & $13.19 \%$ \\
\hline Caquetá & 665,325 & 754,481 & $13.40 \%$ & 132,491 & 162,102 & $22.35 \%$ & 211,660 & 221,332 & $4.57 \%$ \\
\hline La Guajira & 592,560 & 684,238 & $15.47 \%$ & 61,302 & 67,231 & $9.67 \%$ & 141,224 & 163,665 & $15.89 \%$ \\
\hline Arauca & 352,420 & 410,385 & $16.45 \%$ & 61,723 & 71,204 & $15.36 \%$ & 108,703 & 130,880 & $20.40 \%$ \\
\hline Putumayo & 298,221 & 350,157 & $17.42 \%$ & 88,434 & 111,962 & $26.61 \%$ & 52,919 & 62,980 & $19.01 \%$ \\
\hline Chocó & 259,258 & 300,016 & $15.72 \%$ & 26,625 & 39,577 & $48.65 \%$ & 47,745 & 50,021 & $4.77 \%$ \\
\hline \multicolumn{10}{|l|}{ San Andrés $Y$} \\
\hline Providencia & 240,284 & 270,270 & $12.48 \%$ & 2,235 & 3,020 & $35.12 \%$ & 127,949 & 138,916 & $8.57 \%$ \\
\hline Amazonas & 98,417 & 118,522 & $20.43 \%$ & 1,406 & 1,821 & $29.52 \%$ & 22,186 & 28,608 & $28.95 \%$ \\
\hline Guaviare & 75,382 & 84,331 & $11.87 \%$ & 17,588 & 20,962 & $19.18 \%$ & 25,322 & 24,987 & $-1.32 \%$ \\
\hline Vichada & 56,479 & 61,693 & $9.23 \%$ & 8,645 & 9,831 & $13.72 \%$ & 13,083 & 12,924 & $-1.22 \%$ \\
\hline Antioquia & 46,487 & 52,192 & $12.27 \%$ & 697 & 818 & $17.36 \%$ & 33,681 & 37,485 & $11.29 \%$ \\
\hline Guainia & 2,405 & 2,959 & $23.04 \%$ & 1,181 & 1,923 & $62.83 \%$ & 924 & 777 & $-15.91 \%$ \\
\hline Vaupés & 1,688 & 2,656 & $57.35 \%$ & 711 & 1,512 & $112.66 \%$ & 535 & 638 & $19.25 \%$ \\
\hline Other & $42,084,000$ & $47,060,421$ & - & 192,709 & 450,549 & - & $35,180,021$ & $38,389,754$ & \\
\hline Total National & $242,086,987$ & $274,665,695$ & $13.46 \%$ & $7,127,809$ & $8,364,148$ & $17.35 \%$ & $153,046,808$ & $171,184,240$ & $11.85 \%$ \\
\hline
\end{tabular}

As shown Microcredit follows only partiallya geographical distribution similarto distribution of other products and total gross portfolio. The distribution for department is the following:

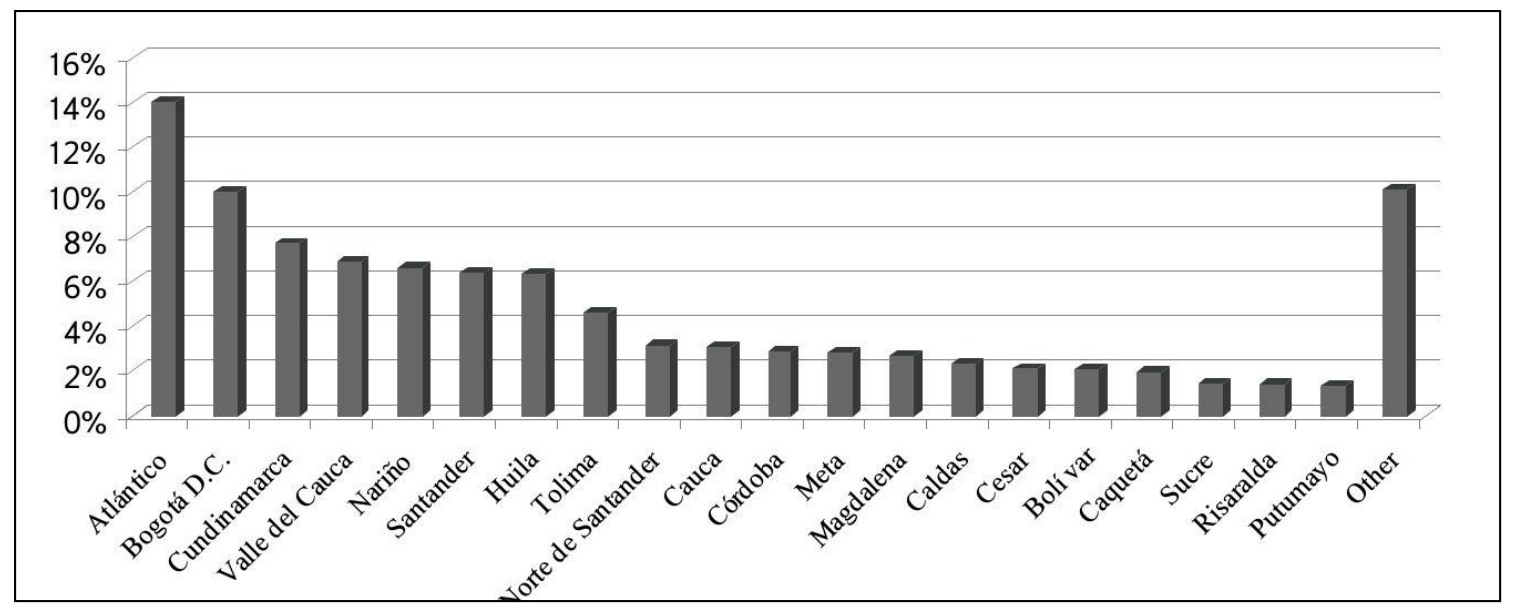

Figure 1. Distribution of the Portfolio of the department for microcredit (in\%)

Source: Our elaboration on DANE data, Superintendencia Financiera de Colombia, the Superintendencia de Economia Solidaria. 
The districts in which microcredit is better developed, as can be seen from the chart, are Atlántico, Bogota, Cundinamarca and Valle del Cauca and, therefore, the situation reflects the geographic concentration of the portfolio gross. As regard the composition of the gross portfolio, it follows the distribution of Microcredit with Bogotà at $45.29 \%$, Valle del Cauca 8.98\%, Atlantico 5.79\% and Santander with 4.19\%.

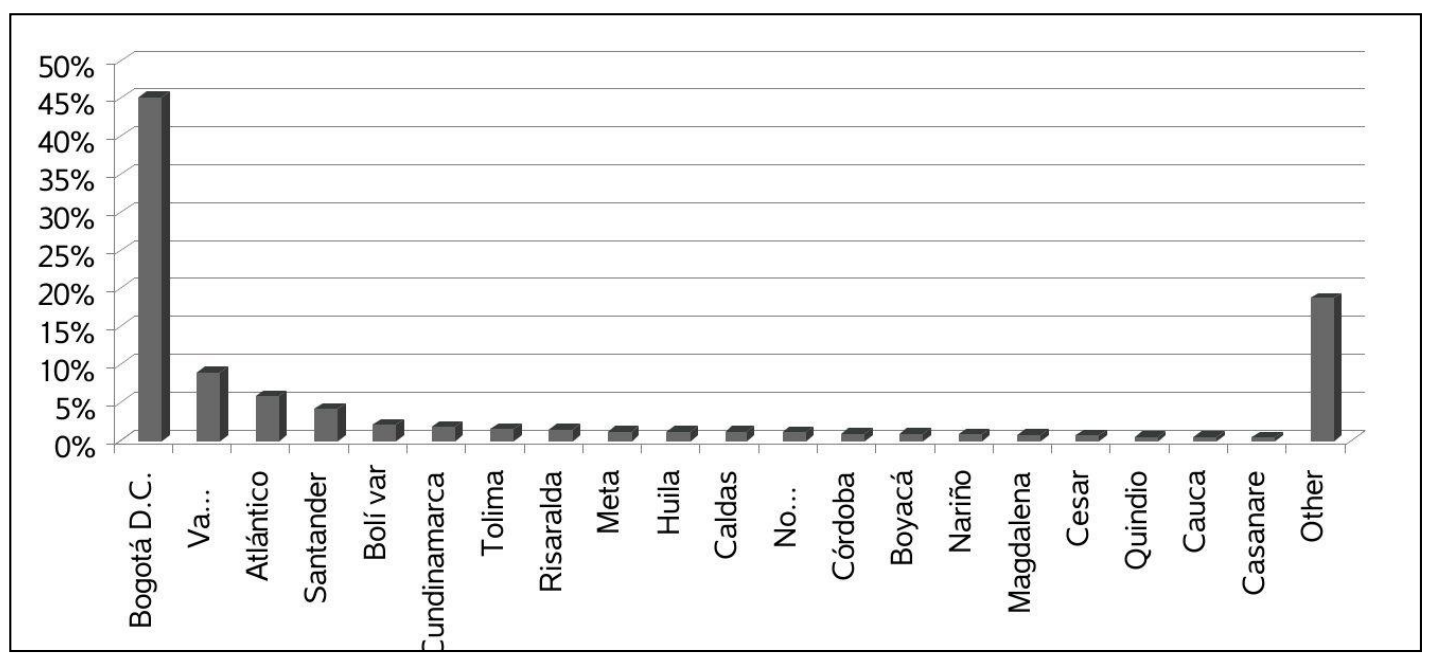

Figure 2. Composition of the gross portfolio of main districts (2013)

Source: our elaboration on data DANE, Superintendencia Financiera de Colombia, the Superintendencia de Economia Solidaria.

About the portfolio of credit for house purchase, the districts where it is most developed are Bogotá with 50.8\%, Valle del Cauca with $11.5 \%$, with $7.8 \%$ and Atlántico Tolima with $4.09 \%$.

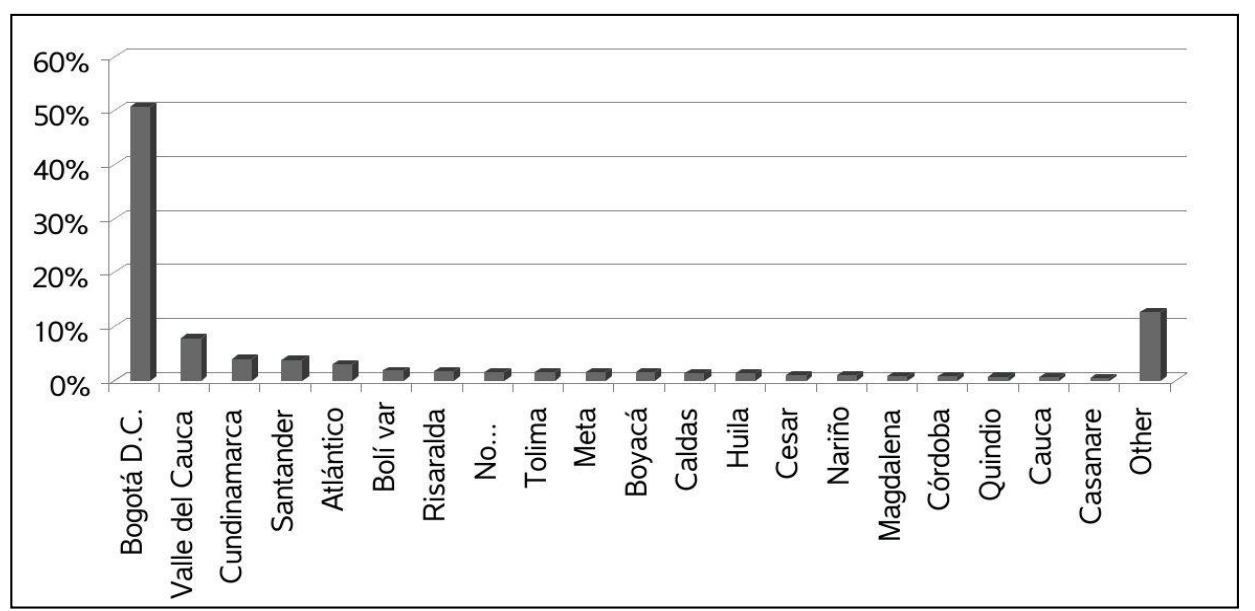

Figure 3. Composition of the portfolio of credit for the purchase of housing the main districts (2013) Sources: DANE, Superintendencia Financiera de Colombia, the Superintendencia de Economia Solidaria.

The portfolio of consumer credit and leasing, also follows the same trend of the portfolio of credit for house purchase and, therefore, is more developed in the districts of Bogotá with 45\%, Valle del Cauca, with $13.7 \%$, with 9.2\% Atlántico and Bolívar with 4.09\%. 


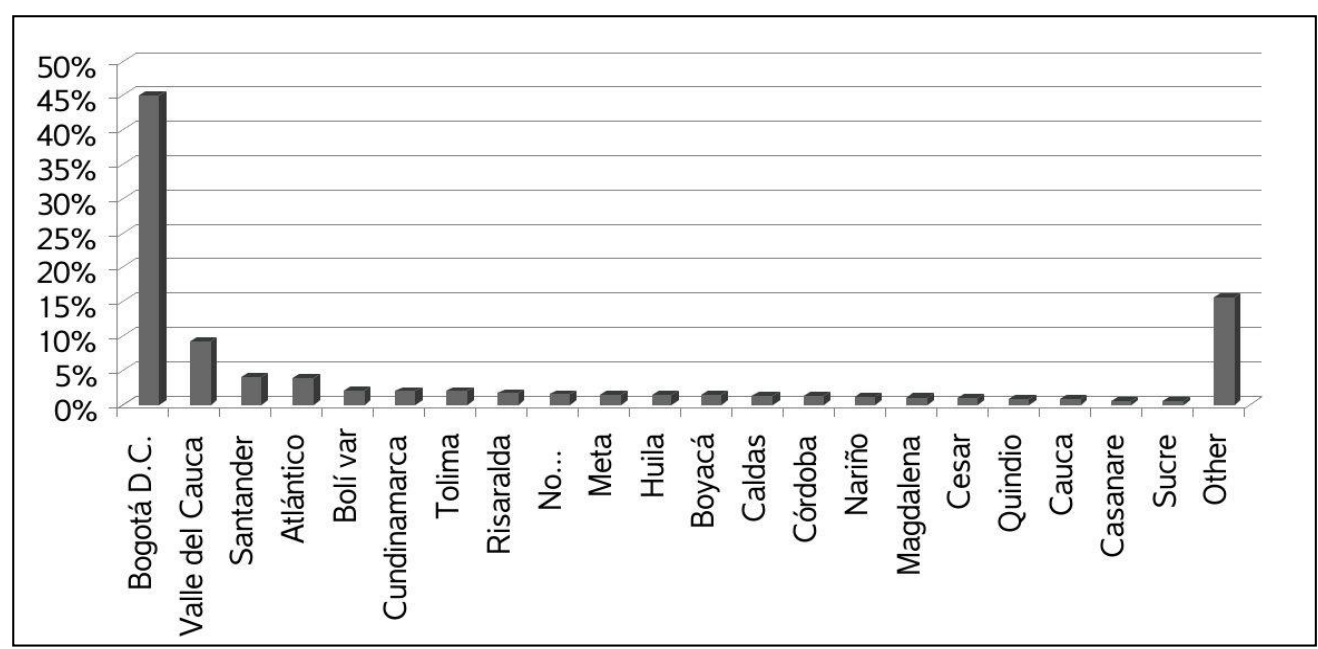

Figure 4. Composition of the portfolio of credit and leasing of consumption of main districts (2013)

Sources: DANE, Superintendencia Financiera de Colombia, the Superintendencia de Economia Solidaria.

Furthermore, concerning the portfolio of the credit and leasing ordinary, it also faithfully follows the distribution of the portfolio of the credit for the purchase of house and the consumer credit and leasing and, consequently, is more developed in the district of Bogota with $46 \%$, Valle del Cauca with $22.43 \%$, Atlántico with $9.2 \%$ and Santander with $6.3 \%$.

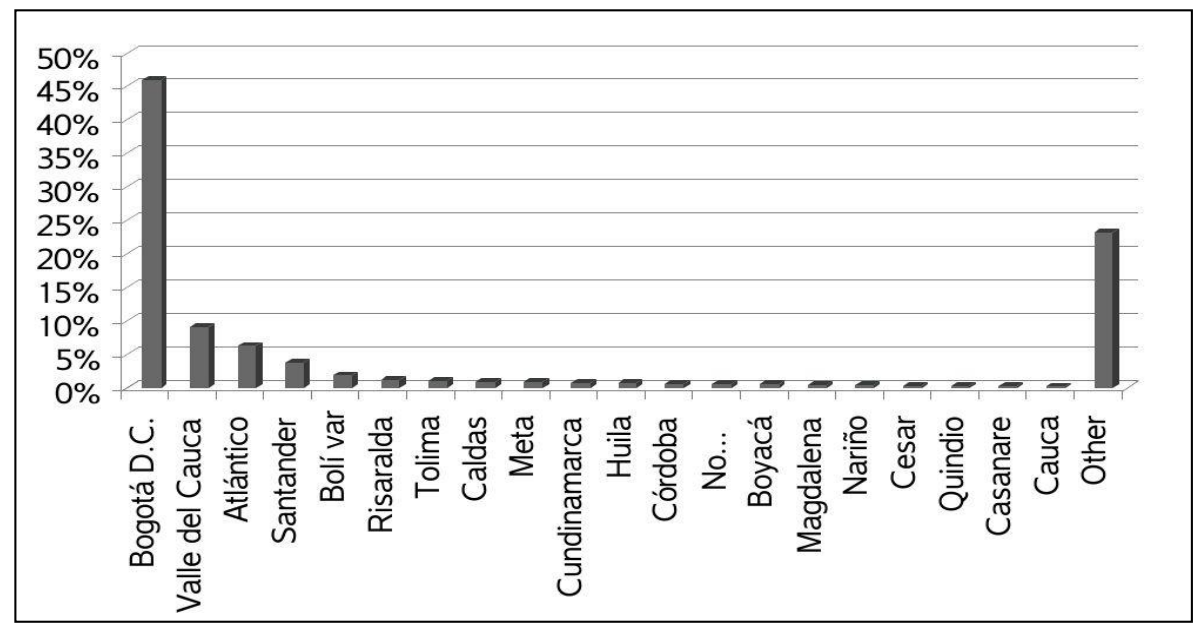

Figure 5. Composition of the portfolio of credit and ordinary leasing main districts (2013)

Sources: DANE, Superintendencia Financiera de Colombia, the Superintendencia de Economia Solidaria.

So the portfolio of microcredithas a more homogenous distribution than other portfolios. The main reason of these differences in the distribution of the portfolio is the fact that microcredit is offered mainly to rural areas of the various districts, while the traditional credit is aimed mostly to urban areas of the country. The second reason, closely related to the first, is that while the traditional lines of credit are aimed at the population and at richest enterprises, microcredit is mostly offered to those persons who have higher difficulty to repay the sums borrowed at higher interest rates.

\section{The Analysis of Microcredit Institutions}

Following the classification of banks, cooperatives, NGOs and NBFI and ordering them according to an increasing scale of the loan portfolio, the companies analyzed are distinct considering the following variables: the loan portfolio in dollars, number of customers, customer credit in dollars, value of the deposits and the value of the equity, interest rate on microcredit, loss rate of the loan portfolio, the risk portfolio for delays that go from 
30 to 90 days, hedge rate.

In addition, for the same companies financial needs was estimated on the basis of residual ratio:

* Net requirement of the loans portfolio $=$ Credits - Deposits - Equity

* Net requirement ratio $=($ Loans - Deposits - Equity $) /$ Loans

Table 8. Entities operating in the field of microfinance (1)

\begin{tabular}{|c|c|c|c|c|c|c|c|}
\hline $\begin{array}{l}\text { Microfinance } \\
\text { Financial } \\
\text { Institutions }\end{array}$ & $\begin{array}{c}\text { Loan } \\
\text { portfolio } \\
\text { (USD }\end{array}$ & Customers & $\begin{array}{l}\text { Loan for } \\
\text { customer } \\
\text { (USD) }\end{array}$ & $\begin{array}{c}\text { Deposits } \\
\text { (USD) }\end{array}$ & $\begin{array}{l}\text { Equity } \\
\text { (USD) }\end{array}$ & $\begin{array}{l}\text { Net requirement of } \\
\text { the loan portfolio } \\
\text { (USD) }\end{array}$ & $\begin{array}{c}\text { Index of net } \\
\text { requirement }(\%)\end{array}$ \\
\hline FiMSA & 249,000 & 1,000 & 249 & 0 & 298,800 & $-49,800$ & $-20.00 \%$ \\
\hline FASE & 332,394 & 790 & 421 & 0 & 590,169 & $-257,775$ & $-77.55 \%$ \\
\hline Ecofin & 387,799 & 446 & 870 & 0 & 235,468 & 152,331 & $39.28 \%$ \\
\hline OLC & 674,292 & 1,437 & 469 & 0 & 594,753 & 79,539 & $11.80 \%$ \\
\hline AVANSAR & 721,579 & 448 & 1,611 & 0 & 847,610 & $-126,031$ & $-17.47 \%$ \\
\hline AGAPE & 965,505 & 6,789 & 142 & 0 & $1,016,876$ & $-51,371$ & $-5.32 \%$ \\
\hline Producir & 999,475 & 1,206 & 829 & 0 & 941,626 & 57,849 & $5.79 \%$ \\
\hline OILA & $1,319,101$ & 6,416 & 206 & 0 & 264,796 & $1,054,305$ & $79.93 \%$ \\
\hline FUNDESCAT & $2,491,929$ & 1,587 & 1,570 & 0 & $1,262,533$ & $1,229,396$ & $49.34 \%$ \\
\hline COOTREGUA & $2,740,646$ & 1,194 & 2,295 & $1,263,911$ & $1,398,451$ & 78,284 & $2.86 \%$ \\
\hline COOSERFIN & $3,292,071$ & 1,212 & 2,716 & 0 & 434,387 & $2,857,684$ & $86.81 \%$ \\
\hline FUNDESAN & $3,372,577$ & 2,990 & 1,128 & 0 & $1,156,917$ & $2,215,660$ & $65.70 \%$ \\
\hline Alcaravan & $3,171,161$ & 2,422 & 1,521 & 0 & $4,953,727$ & $-1,782,566$ & $-56.21 \%$ \\
\hline FUNDESMAG & $2,319,618$ & 1,406 & 2,807 & 0 & $1,691,595$ & 628,023 & $27.07 \%$ \\
\hline Coomultagro & $5,035,951$ & 1,769 & 2,847 & $2,994,340$ & $1,539,462$ & 502,149 & $9.97 \%$ \\
\hline COMERCIACOOP & $5,386,696$ & 7,079 & 761 & $3,853,095$ & $1,661,949$ & $-128,348$ & $-2.38 \%$ \\
\hline ActuarQuindio & $6,298,594$ & 3,535 & 1,782 & 0 & $1,745,813$ & $4,552,781$ & $72.28 \%$ \\
\hline FMSD & $5,986,058$ & 5,211 & 1,220 & 0 & $167,686,926$ & $-161,700,868$ & $-2701.29 \%$ \\
\hline ActuarTolima & $6,545,160$ & 9,090 & 720 & 0 & $4,512,111$ & $2,033,049$ & $31.06 \%$ \\
\hline Actuar Caldas & $6,853,241$ & 5,365 & 1,399 & 0 & $3,114,619$ & $3,738,622$ & $54.55 \%$ \\
\hline COFINCAFE & $18,389,830$ & 16,226 & 1,154 & $15,784,553$ & $5,510,745$ & $-2,905,468$ & $-15.80 \%$ \\
\hline
\end{tabular}

Source: Ourelaboration on MixMarket, website of entities, Banco de la Repùblica, SuperintendenciaFinanciera de Colombia, Superintendencia de la Economia Solidaria.

Table 9. Entities operating in the field of microfinance (2)

\begin{tabular}{cccccc}
\hline $\begin{array}{c}\text { Microfinance Financial } \\
\text { Institutions }\end{array}$ & $\begin{array}{c}\text { Interest rate on } \\
\text { Microcredit (COP) }\end{array}$ & $\begin{array}{c}\text { Loss rate of the } \\
\text { portfolio }\end{array}$ & $\begin{array}{c}\text { Portfolio risk> } \\
\mathbf{3 0 ~ d a y s}\end{array}$ & $\begin{array}{c}\text { Portfolio risk> } \\
\mathbf{9 0} \text { days }\end{array}$ & $\begin{array}{c}\text { Rate hedging } \\
\text { of risk }\end{array}$ \\
\hline FiMSA & - & - & - & - & - \\
FASE & - & $7.01 \%$ & $16.47 \%$ & $7.69 \%$ & - \\
Ecofin & - & $8.10 \%$ & $7.54 \%$ & $2.59 \%$ & $115.87 \%$ \\
OLC & - & $14.50 \%$ & $6.37 \%$ & $4.12 \%$ & $81.25 \%$ \\
AVANSAR & - & $2.97 \%$ & $14.61 \%$ & $8.56 \%$ & $20.15 \%$ \\
AGAPE & - & $8.51 \%$ & $6.68 \%$ & $4.99 \%$ & $54.89 \%$ \\
Producir & - & - & $16.38 \%$ & $9.58 \%$ & $63.48 \%$ \\
OILA & - & $7.59 \%$ & $6.09 \%$ & $3.30 \%$ & $87.03 \%$ \\
\hline
\end{tabular}




\begin{tabular}{cccccc}
\hline FUNDESCAT & $39.12 \%$ & - & $1.44 \%$ & $0.85 \%$ & $151.39 \%$ \\
COOTREGUA & - & - & - & - & - \\
COOSERFIN & - & - & - & - & $0.87 \%$ \\
FUNDESAN & $18.27 \%$ & $0.08 \%$ & $3.99 \%$ & $0.68 \%$ & $2.32 \%$ \\
Alcaravan & $42.70 \%$ & $2.29 \%$ & $2.91 \%$ & - & $42.32 \%$ \\
FUNDESMAG & $26.28 \%$ & - & $3.84 \%$ & $1.42 \%$ & $87.42 \%$ \\
Coomultagro & $21.60 \%$ & $1.16 \%$ & $2.25 \%$ & $3.63 \%$ & $100.42 \%$ \\
COMERCIACOOP & $25.75 \%$ & $0.18 \%$ & $4.32 \%$ & $0.97 \%$ & $100.00 \%$ \\
ActuarQuindio & $39.60 \%$ & $1.30 \%$ & $1.88 \%$ & $8.21 \%$ & $97.95 \%$ \\
FMSD & $36.00 \%$ & $-0.29 \%$ & $14.07 \%$ & $3.21 \%$ & $116.83 \%$ \\
ActuarTolima & $51.41 \%$ & $2.26 \%$ & $5.45 \%$ & $3.42 \%$ & $114.45 \%$ \\
Actuar Caldas & $31.30 \%$ & $0.76 \%$ & $6.87 \%$ & - & - \\
COFINCAFE & - & - & - & & - \\
\hline
\end{tabular}

Table 10. Entities operating in the field of microfinance (3)

\begin{tabular}{|c|c|c|c|c|c|c|c|}
\hline $\begin{array}{c}\text { Microfinance } \\
\text { Financial Institutions }\end{array}$ & $\begin{array}{c}\text { Loan } \\
\text { portfolio } \\
\text { (USD) }\end{array}$ & Customers & $\begin{array}{c}\text { Loan per } \\
\text { customer } \\
\text { (USD) }\end{array}$ & $\begin{array}{l}\text { Deposits } \\
\text { (USD) }\end{array}$ & $\begin{array}{l}\text { Equity } \\
\text { (USD) }\end{array}$ & $\begin{array}{c}\text { Net requirement of } \\
\text { the loan portfolio } \\
\text { (USD) }\end{array}$ & $\begin{array}{c}\text { Index of net } \\
\text { requirement } \\
(\%)\end{array}$ \\
\hline FundaciónAmanecer & $21,566,227$ & 11,020 & 1,957 & 0 & $9,510,460$ & $12,055,767$ & $55.90 \%$ \\
\hline OI Colombia & $26,196,037$ & - & - & $13,146,286$ & $5,181,702$ & $7,868,049$ & $30.04 \%$ \\
\hline $\begin{array}{l}\text { Microempresas de } \\
\text { Colombia }\end{array}$ & $28,579,288$ & 19,992 & 1,430 & $5,864,174$ & $7,346,722$ & $15,368,392$ & $53.77 \%$ \\
\hline AYF & $47,689,413$ & 11,812 & 4,037 & - & - & - & - \\
\hline $\begin{array}{l}\text { Cooperativa } \\
\text { Microempresas de } \\
\text { Colombia }\end{array}$ & $52,393,133$ & 29,094 & 1,801 & $6,786,807$ & $8,774,082$ & $36,832,244$ & $70.30 \%$ \\
\hline Interactuar & $54,050,000$ & 32,247 & 1,818 & 0 & $30,570,000$ & $23,480,000$ & $43.44 \%$ \\
\hline CMM Bogotá & $58,925,299$ & 72,275 & 815 & 0 & $8,314,281$ & $50,611,018$ & $85.89 \%$ \\
\hline Contactar & $61,023,548$ & 72,383 & 878 & 0 & $15,613,263$ & $45,410,285$ & $74.41 \%$ \\
\hline CMM Medellín & $68,196,713$ & 66,377 & 1,027 & 0 & $8,644,727$ & $59,551,986$ & $87.32 \%$ \\
\hline Crezcamos & $64,675,411$ & 69,378 & 1,029 & 0 & $18,256,425$ & $46,418,986$ & $71.77 \%$ \\
\hline ProCredit - COL & $92,937,959$ & - & - & $84,370,297$ & $19,675,832$ & $-11,108,170$ & $-11.95 \%$ \\
\hline FinAmérica & $257,979,717$ & 94,805 & 2,721 & $254,666,129$ & $41,918,084$ & $-38,604,496$ & $-14.96 \%$ \\
\hline Confiar & $262,267,617$ & 48,350 & 5,424 & $200,053,457$ & $42,652,916$ & $19,561,244$ & $7.46 \%$ \\
\hline FundaciónDelamujer & $307,324,746$ & 352,529 & 777 & 0 & $116,939,258$ & $190,385,488$ & $61.95 \%$ \\
\hline Banco WWB & $386,017,640$ & 206,405 & 1,870 & $104,485,939$ & $216,955,854$ & $64,575,847$ & $16.73 \%$ \\
\hline Comultrasan & $402,653,414$ & 93,689 & 4,298 & $273,187,032$ & $136,906,228$ & $-7,439,846$ & $-1.85 \%$ \\
\hline FundaciónMundoMujer & $483,712,815$ & 531,240 & 869 & 0 & $312,942,849$ & $170,769,966$ & $35.30 \%$ \\
\hline Bancamía & $495,054,792$ & 365,389 & 1,355 & $182,795,911$ & $150,567,908$ & $161,690,973$ & $32.66 \%$ \\
\hline Banco Caja Social & $539,026,922$ & 675,370 & 798 & $4,333,207,631$ & $671,984,482$ & $-4,466,165,191$ & $-828.56 \%$ \\
\hline Fomentamos & $702,952,613$ & - & - & 0 & $27,840,824$ & $675,111,789$ & $96.04 \%$ \\
\hline B. Colombia Microfin. & $9,301,778,541$ & - & - & - & - & - & - \\
\hline
\end{tabular}

Source: Our elaboration on MixMarket, websites of entities, Banco de la Repùblica, SuperintendenciaFinanciera de Colombia, Superintendencia de la Economia Solidaria. 
Table 11. Entities operating in the field of microfinance (4)

\begin{tabular}{|c|c|c|c|c|c|}
\hline Microfinance Financial Institutions & $\begin{array}{c}\text { Interest rate on } \\
\text { Microcredit (COP) }\end{array}$ & $\begin{array}{c}\text { Loss rate of the } \\
\text { portfolio }\end{array}$ & $\begin{array}{c}\text { Portfolio } \\
\text { risk> } 30 \text { days }\end{array}$ & $\begin{array}{c}\text { Portfolio } \\
\text { risk> } 90 \text { days }\end{array}$ & $\begin{array}{c}\text { Rate hedging } \\
\text { of risk }\end{array}$ \\
\hline FundaciónAmanecer & - & $3.52 \%$ & $3.92 \%$ & $1.95 \%$ & $150.96 \%$ \\
\hline OI Colombia & $52.21 \%$ & - & - & - & - \\
\hline Microempresas de Colombia & $31.20 \%$ & - & $4.05 \%$ & - & - \\
\hline AYF & - & - & - & - & - \\
\hline Cooperativa Microempresas de Colombia & $36.07 \%$ & $2.85 \%$ & $2.06 \%$ & $1.39 \%$ & $88.11 \%$ \\
\hline Interactuar & $31.24 \%$ & $0.00 \%$ & $8.55 \%$ & $6.53 \%$ & $84.07 \%$ \\
\hline CMM Bogotá & - & $0.40 \%$ & $1.98 \%$ & $1.40 \%$ & $124.60 \%$ \\
\hline Contactar & $35.75 \%$ & $0.69 \%$ & $1.80 \%$ & $1.41 \%$ & $132.32 \%$ \\
\hline CMM Medellín & - & $0.81 \%$ & $1.78 \%$ & $1.57 \%$ & $124.17 \%$ \\
\hline Crezcamos & $40.33 \%$ & $1.79 \%$ & $3.01 \%$ & $1.56 \%$ & $118.23 \%$ \\
\hline ProCredit - COL & $39.02 \%$ & - & - & - & - \\
\hline FinAmérica & $47.00 \%$ & $4.18 \%$ & $10.67 \%$ & $8.22 \%$ & $75.52 \%$ \\
\hline Confiar & $32.75 \%$ & $0.74 \%$ & $3.83 \%$ & $2.28 \%$ & $131.02 \%$ \\
\hline FundaciónDelamujer & $37.30 \%$ & $2.93 \%$ & $4.40 \%$ & $2.72 \%$ & $104.00 \%$ \\
\hline Banco WWB & $45.90 \%$ & $2.54 \%$ & $7.70 \%$ & $6.59 \%$ & $100.99 \%$ \\
\hline Comultrasan & - & $1.08 \%$ & $3.44 \%$ & $2.24 \%$ & $221.98 \%$ \\
\hline FundaciónMundoMujer & - & $1.78 \%$ & $2.45 \%$ & $1.58 \%$ & $104.00 \%$ \\
\hline Bancamía & $37.55 \%$ & $5.39 \%$ & $6.28 \%$ & $4.32 \%$ & $82.12 \%$ \\
\hline Banco Caja Social & $34.83 \%$ & $10.26 \%$ & $6.10 \%$ & $3.91 \%$ & $82.56 \%$ \\
\hline Fomentamos & $40.50 \%$ & $1.82 \%$ & $0.52 \%$ & $0.27 \%$ & $427.23 \%$ \\
\hline BancolombiaMicrofinanzas & $38.60 \%$ & - & - & - & - \\
\hline
\end{tabular}

The most important thing is that on average the interest rates on microcredit are 2.5 times bigger than the interest rates on ordinary loans. In fact on average the interest rate on loans of micro credit is $29.87 \%$, compared with an average interest rate on ordinary credit equal to $11.96 \%$.

\section{Conclusion}

In conclusion, according to the analyzed variables, it can be said that the framework of Microcredit represent a founding opportunity for micro-enterprises in Colombia and an investment opportunity for investors who collect funds on the international market, and use them in Microcredit sector. The high interest rates on microcredit in Colombia guarantee adequate profit margins even when such investors borrow money at higher rates than rates that are usually present in international market. In fact we have to highlight that the Microcredit is a high risk investment which presupposes expected return more considerable.

\section{References}

Alessandrini, P., Andrea, F. P., \& Alberto, Z. (2010). Bank size or distance: What hampers innovation adoption by SMEs? Journal of Economic Geography, 10(6), 845-881. http://dx.doi.org/10.1093/jeg/lbp055

Armendáriz, B., \& Morduch, J. (2005). The economics of microfinance (p. 346). Boston: MIT Press.

Armendáriz, B., \& Vanroose, A. (2009). Uncovering microfinance myths: Does country-wide age matter? Reflets et Perspectives de la Vie conomique, XLVIII(3), 7-17.

Banerjee, A., Esther, D., Glennerster, R., \& Cynthia, K. (2010). The miracle of microfinance: Evidence from a randomized evaluation. MIT.

Bateman, M., \& Ha-Joon, C. (2009). The microfinance illusion. Technical report University of Cambridge and University of Juraj Dobrila Pula. http://dx.doi.org/10.2139/ssrn.2385174 
Bateman, M., Juan, P. D. O., \& Dean, S. (2011). Microfinance in Ultrapoor communities: The experience of Medellin, Colombia. In M. Bateman (Ed.), Confronting microfinance-undermining sustainable development. Herndon, VA: Kumarian Press.

Beck, T., \& Asli, D. K. (2008). Access to finance: An unfinished agenda. World Bank Economic Review, 22(3), 383-396. http://dx.doi.org/10.1093/wber/lhn021

Beck, T., \& Asli, D. K. (2009). Financial institutions and markets across countries and over time: Data and analysis. World Bank Policy Research Working Paper 4943, The World Bank Washington DC. http://dx.doi.org/10.1596/1813-9450-4943

Beck, T., \& Maria, S. M. P. (2010). Foreign bank participation and outreach: Evidence from Mexico. Journal of Financial Intermediation, 19(1), 52-73. http://dx.doi.org/10.1016/j.jfi.2009.03.002

Beck, T., Asli, D. K., \& Ross, L. (2000). A new database on financial development and structure. World Bank Economic Review, (14), 597-605. http://dx.doi.org/10.1093/wber/14.3.597

Berger, M., Goldmark, L., \& Miller-Sanabria, T. (Eds.) (2006). An inside view of Latin American microfinance (p. 305). Inter-American Development Bank.

Besley, T., \& Stephen, C. (1995). Group lending, repayment incentives and social collateral. Journal of Development Economics, 46(1), 1-18. http://dx.doi.org/10.1016/0304-3878(94)00045-E

Christen, R. P. (2001). Commercialization and mission drift: The transformation of microfinance in Latin America. Occasional Papers, No. 5, Consultative Group to Assist the Poor (CGAP), The World Bank, Washington D. C.

Clarke, G., Robert, C., Maria, S. M. P., \& Susana, M. S. (2005). Bank lending to small businesses in Latin America: Does bank origin matter? Journal of Money, Credit and Banking, 37(1), 83-118. http://dx.doi.org/10.1353/mcb.2005.0003

Conger, L., Inga, P., \& Webb, R. (2009). The Mustard tree: A history of microfinance in Peru (p. 176). Universidad de San Martin de Porres, Lima.

Cull, R., Demirguc-Kunt, A., \& Morduch, J. (2007). Financial performance and outreach: A global analysis of leading.

Degryse, H., Moshe, K., \& Steven, O. (2009). Microeconometrics of banking: Methods, applications, and results. Oxford: Oxford University Press. http://dx.doi.org/10.1093/acprof:oso/9780195340471.001.0001

Ghatak, M., \& Guinnane, T. (1999). The economics of lending with joint liability. Journal of Development Economics, 60, 195-228. http://dx.doi.org/10.1016/S0304-3878(99)00041-3

Goldfajn, I., \& Rigobon, R. (2000). Hard currency and financial development. Working Paper, No. 438, Pontifica Universidad Catolica-Rio Department of Economics, Rio De Janeiro. Retrieved from http://www.econ.puc-rio.br/pdf/td438.pdf

Gomez, A., Tabares, G., \& Vogel, R. (2001). Regulation and supervision of microfinance: The Bolivian case study. Working Paper Microenterprise Best Practices, Development Alternatives Inc.

Hermes, N., \& Robert, L. (2007). The empirics of microfinance: What do we know? Economic Journal, 117. http://dx.doi.org/10.1111/j.1468-0297.2007.02013.x

Hulme, D., \& Thankom, A. (2009). Microfinance-A reader. Routledge Studies in Development Economics, London: Routledge.

Molini, V., \& Roberta, R. (2008). Microfinance and development: Two Latin American case studies. SeMeQ working paper 06/2008 Università del Piemonte Orientale.

Navajas, S., \& Luis, T. (2006). Microfinance in Latin America and the Caribbean: How large is the market? Sustainable development department best practices series Inter-American Development Bank Washington DC.

Oke, J. T. O., Adeyemo, R., \& Agbonlahor, M. U. (2007). An empirical analysis of microcredit repayment in Southwestern Nigeria. Humanities and Social Sciences Journal, 2(1), 63-74. http://dx.doi.org/10.1300/10911350802081592

Patten, R. H., Rosengard, J. K., \& Johnston, D. E. (2001). Microfinance success amidst macroeconomic failure: The experience of bank Rakyat Indonesia during the East Asian Crisis. World Development, 29(6), 1057-1069. http://dx.doi.org/10.1016/S0305-750X(01)00016-X 
Paulson, A. (2002). Human capital and the development of financial institutions: Evidence from Thailand. Working Paper, Federal Reserve Bank of Chicago.

Ramirez, A. (2004). The microfinance experience in Latin American and the Caribbean. Workshop Paper, LAEBE Research Conference on Microfinance in Latin America and Asia, Asian Development Bank Institute, Pihilippines.

Rhyne, E. H. (2001). Mainstreaming microfinance: How lending to the poor began, grew and came of age in Bolivia. Bloomfield: Kumarian Press.

Richter, P. (2004). The integration of the microfinance sector in the financial sector in developing countries: The role that Apex Mechanims play in Uganda. Paper Presented at Unlocking Human Potential, Linking the Informal and Formal Sectors, WIDER Conference, Finland, September 2004.

Robinson, S. M. (2001). The microfinance revolution: Sustainable finance for the poor. The World Bank and Open Society Institute, Washington D.C. http://dx.doi.org/10.1596/0-8213-4524-9

Schneider, F., \& Buehn, A. (2007). Shadow economies and corruption all over the world: Revised estimates for 120 countries. Economics: The Open Access, Open Assessment E-Journal, 1, 2007-2009.

Schreiner, M., \& Colombet, H. H. (2001). From urban to rural: Lessons for microfinance from Argentina. Development Policy Review, 19(3), 339-354. http://dx.doi.org/10.1111/1467-7679.00138

\section{Copyrights}

Copyright for this article is retained by the author(s), with first publication rights granted to the journal.

This is an open-access article distributed under the terms and conditions of the Creative Commons Attribution license (http://creativecommons.org/licenses/by/3.0/). 